\title{
4 \\ Do transgenic food fulfill the obligations of respecting food security and nutritional concept in a developing country?
}

\author{
Elaine Gomes Fiore ${ }^{1 *}$, Cristiane Tavares Matias ${ }^{1}$, Fabiane Alessandra Bee ${ }^{2}$ e \\ Mariangela de Almeida ${ }^{2}$
}

This study seeks to identify whether a developing country fulfills the obligations of respecting the Food and Nutritional Security when producing and commercializing transgenic foods. A bibliographic research was carried. The author's arguments are based on the concept of Food and Nutritional Security, its interface with the Human Right to Adequate Food, and the food and nutritional dimensions of the theme. The technology of transgenics, when used in a massive way for protection against insects and weeds, is not always safe. The use of certain herbicides, linked to production control, can also be deleterious. Epidemiological studies on the nutritional advantages are insufficient and the possibility of allergenicity exists, if the protocols for seed release are not considered. Lack of enforcement in these protocols and in labeling threaten Food Safety, since the population is vulnerable to the consumption of foods whose origin are not well known. Even with the transgenic food, a bigger amount of food is not available for everybody. The importance of food and nutritional education is emphasized in this study. Since the concept of Food and Nutritional Security is indivisible, we conclude that Food and Nutritional Security in a developing country is not fulfilled.

Keywords: food and nutritional security, sustainable agriculture, transgenic foods, genetically modified organisms.

\section{Os alimentos transgênicos cumprem as obrigações de respeitar a segurança alimentar e nutricional em um país em desenvolvimento?}

Este estudo busca identificar se um país em desenvolvimento cumpre as obrigações de respeitar a Segurança Alimentar e Nutricional ao produzir e comercializar alimentos transgênicos. Trata-se de pesquisa bibliográfica. Tomou-se por base o conceito de Segurança Alimentar e Nutricional, sua interface com o Direito Humano à Alimentação Adequada e as dimensões alimentar e nutricional do tema. A tecnologia dos transgênicos, quando utilizada de forma massiva para proteção contra os insetos e contra ervas daninhas nem sempre é segura. O uso de determinados herbicidas, ligados ao controle da produção, também pode ser deletério. Estudos epidemiológicos sobre vantagens nutricionais são insuficientes e há possibilidade de alergenicidade caso sejam desconsiderados os protocolos para liberação das sementes. A falta de fiscalização no cumprimento destes protocolos e da rotulagem ameaçam a Segurança Alimentar, dada a vulnerabilidade da população ao consumo desconhecido. $\mathrm{O}$ acesso a maior

1 Programa de Pós-Graduação Interunidades em Nutrição Humana Aplicada - PRONUT, Universidade de São Paulo, Brasil. Endereço para correspondência: Av. Rebouças no 1.164, apto. 4, São Paulo, Brasil. Tel: +55-11-2129-8262. E-mail: elainefi@live.com

2 Centro Universitário Padre Anchieta, Jundiaí, Brasil. 
quantidade de alimentos não ocorre para todos. Ressalta-se no estudo a importância da educação alimentar e nutricional. Dado que o conceito de Segurança Alimentar e Nutricional é indivisível, conclui-se que a mesma não está sendo cumprida em um país em desenvolvimento.

Palavras-chave: segurança alimentar e nutricional, agricultura sustentável, alimentos transgênicos, organismos geneticamente modificados.

\section{INTRODUCTION}

\section{Overview}

In Brazil, the concept of Food and Nutritional Security has evolved because of the popular struggles against hunger and democratization, in search of a country with economic and social equity ${ }^{[1]}$.

The Organic Law on Security and Nutritional Food created the Food Security and Nutritional System to ensure the Human Right to Adequate Food ${ }^{[2]}$ and has ratified the concept of Food and Nutritional Security approved at the Second Food and Nutritional Security Conference:

Food and Nutritional Security consists on realization of everybody's right to regular and permanent access to quality food in enough quantity, without compromising access to other essential needs, based on food practices that promote health and respect cultural diversity and are environmentally, culturally, economically and socially sustainable.

Brazil is internationally committed to assume its obligations to enforce Human Rights and make sure that nobody will violate them through respect, protection and realization of those rights when it became a signatory of the International Pact for Economic, Social and Cultural Rights ${ }^{[3]}$. Due to the interconnection and interdependence between Food and Nutritional Security and the Human Right to Adequate Food public policies created from the national conferences in Brazil to ensure Food and Nutritional Security should also extend guarantees to Human Right to Adequate Food[4].

Subsequently, the National Policy on Food and Nutritional Security (Política Nacional de Segurança Alimentar e Nutricional) in Brazil, approved in 2010, established as a purpose to ensure Food and
Nutritional Security. The second guideline of the referred policy is to promote the supply and structure for sustainable and centralized systems of agro ecological, production, extraction, processing and distribution of food[5].

Based on the Brazilian National Policy of Food and Nutritional Security (Política Nacional de Segurança Alimentar e Nutricional), Food and Nutritional Security Plan (Plano de Segurança Alimentar e Nutricional) are established. The second Food and Nutritional Security Plan refers to the challenges and strategies for the years 2016 to 2019, the third challenge being the production of healthy and sustainable food, the structuring of family farming and the strengthening of agro ecological production systems, in accordance to the second guideline of the National Policy on Food and Nutritional Security[].

In 2012, the Food and Nutritional National Policy (Política Nacional de Alimentação e Nutrição) was published, considering the situation in Brazil. The second guideline of this policy is related to the Promotion of Adequate and Health Food, that consider the importance of harmonic food, both in quantity and quality, based on productive, adequate and sustainable practices. The fifth guideline concerns food control and regulation to ensure the promotion of adequate and healthy food[7].

It is indispensable to mention that the Constitution of Brazil, in 2010[8], has included food as a right, through a constitutional amendment and that this same document states about the importance of the integrity of the genetic heritage in the country, but also encourages scientific research based on technology. In this situation the researchers can use the legal basis according to their interests and conveniences what can cause noncompliance of Food and Nutritional Security. 


\section{Genetic engineering}

Genetic transformation consists of the controlled introduction of nucleic acids (genes) into a recipient genome using the recombinant DNA technique. It is in DNA that the genetic information responsible for all the characteristics of an organism is found. According to the procedure for the transfer of genes, the techniques of genetic transformation can be of two categories: direct and indirect. While the direct transfer consists of physical or chemical methods that aim to break the wall barrier and/or the plasma membrane for the penetration of DNA into the cell, the indirect transfer consists of the use of vectors (bacteria) capable of transferring part of their DNA to the plants, inducing them to synthesize substances for their growth. Genetic engineering allows the DNA of the bacteria to be altered, with the withdrawal of the harmful genes to the plant and the insertion of genes of interest $t^{[9]}$.

The biotechnology has been used in the production of insulin, for example, and vaccines with antiviral proteins. The use for food, however, affects the whole population and, for this reason, this topic needs to be more studied[10].

Foods with genetically modified organisms were banned in Brazil through a judicial injunction filed by the Consumer Protection Institute in 1998, contrary to the approval of the commercial release of transgenic soy by the National Technical Biosafety Commission (Comissão Técnica Nacional de Biossegurança) constituted by Law 8.974/95[11], which alleged that it did not find evidence of a deleterious effect on health and the environment. The judicial decision prohibiting transgenics, however, was reversed and Law 11.105/2005[12] repealed Law 8.974/1995, establishing safety standards and mechanisms for monitoring activities involving genetically modified organisms.

Since its release, soybean and subsequently other plants such as maize and cotton, are produced and marketed in Brazil, but with the obligation to identify the transgenesis in the packaging ${ }^{[13]}$.

Internationally, there are two aspects of transgenic regulation: The first refers to the principle of
Substantial Equivalence (ES), which compares a genetically modified food to a conventional food, and if it is equivalent, once the conventional does not cause risk to environment and human health, transgenic also offers no risk. In this case, the safety of the genetically modified food would be subordinated to the safety of the original food[14]. This principle has been used by global regulatory authorities, but in practice it is adopted in countries such as the United States. The second aspect refers to the Precautionary Principle (PP), which means to guard against substances that could potentially harm the environment or human health until there is absolute scientific certainty that they are not harmful. This principle is the guarantee against potential risks and was proposed at the Rio Conference 92[15].

The European Union and Brazil use the Precautionary Principle ${ }^{[16,17]}$. According to this principle, conventional food safety is only one of the components of risk analysis.

Both sides are antagonistic, because while Substantial Equivalence disregards possible damages, the Precautionary Principle considers them and has a more prudent stance.

In order to investigate the Food Safety of genetically modified foods, Codex Alimentarius Commission ${ }^{[18]}$ provides a methodology that considers the following aspects: direct health effects, ability to provoke allergies, possibility to promote toxicity, stability of the inserted gene, nutritional effects arising from the transgenesis and unintended effects that may result from genetic insertion.

\section{The situation of transgenic foods in the world}

It is estimated that there are 18 million farmers producing transgenic plants distributed in about 27 countries, mainly involved in the production of soybeans, maize, canola and cotton. The relevance of the analysis of the production of transgenics in Brazil is that it occupies the second position in the world production (23\%), losing only for the United States $(40 \%)$. Argentina produces $14 \%$, Canada and India $6 \%$, and China $2 \%$. All the other countries produce less than $10 \%$. In Europe, several countries ${ }^{3}$ have banned their 
cultivation and transgenics occupy only $0.14 \%$ of the agricultural surface[19].

Both in the United States and in Brazil and Argentina, soybeans, maize and cotton are the most extensively cultivated plants ${ }^{[1]}$. In the United States there is a lot of public opposition to cultivation. The campaign to label transgenic foods is gaining more and more supporters in several countries ${ }^{[20]}$. A bill makes labeling obligatory since July 2016[21]. In this country, it was optional in the past and it was only obligatory in case there was no similar conventional product that adjusted to the principle of substantial equivalence[22].

In Argentina, in spite of high production, in 2013 a statement was made by the scientific community referring to the lack of consensus on the safety of transgenic foods, as well as the absence of epidemiological studies. Besides that, many companies responsible for the marketing of these products carry out many of the researches ${ }^{[23]}$. In fact, there are two epidemiological studies associating the degeneration of the health of the American population in the last twenty years to the expansion of the consumption of genetically modified organisms. Both studies were based on scientific research data from the American population. One of these studies relates the beginning of the consumption of transgenic maize to the obesity epidemic and the other relates glyphosate consumption to diseases such as arterial hypertension, stroke, some neurological and metabolic diseases and leukemia ${ }^{[24,25]}$.

Canola, maize and beet were approved in Canada, and in 2013, genetically modified seafood was also approved. This has been causing a lot of resistance on the part of some scientific communities in other countries, since it is the first time that genetic modification in animals for food was authorized[23]. Currently, at least 35 species of fish are being genetically manipulated all over the world. In 2015 the Food and Drug Administration (FDA) approved a variety of salmon for a company that is also producing genetically modified tilapia and trout to be still approved ${ }^{[26]}$.

India produces insect-resistant $\mathrm{Bt}$ cotton, but the effectiveness of this production has been questioned, both in terms of increased yields and in terms of reduction of pesticide use, fact that has brought serious problems for farmers, especially in rainfed areas, such as the suicide of farmers in consequence of much lower production than expected, crop failures and debts ${ }^{[2]}$.

China also produces insect-resistant cotton. But despite being one of the world's largest rice producers, after several years of scientific debate, it has chosen not to market transgenic rice for five to ten years, since the publication of the determination in 2011, mainly due to the doubts about the absence of risks of transgenic rice and the uncertainty regarding the efficiency in the increase of production ${ }^{[28]}$.

Finally, the European Food Safety Authority (EFSA) has shown interest in carrying out long-term studies on transgenic foods consumption, due to the lack of evidence on the safety and the conflicts of interest that constantly involve transgenic foods research [29]. The United States, Canada and Argentina allege that measures in Europe constitute a regulatory barrier to market access ${ }^{[2]}$.

The evolution of Food and Nutritional Security in Brazil and the related documents show that Brazilians recognize that the production in sustainable systems is indispensable for the healthy food supply, but in spite of that, Brazil occupies the second position among transgenic producing countries, and some aspects related to this technology seem to threaten the accomplishment of Food and Nutritional Security such as uncertainty in food quality and environmental sustainability ${ }^{[30]}$. In addition, although some Brazilian Ministries are responsible for supervising the entire food production chain, the inspection policy is still incipient ${ }^{[31]}$.

The purpose of this article is to identify, through bibliographic research and based on the concepts of Food and Nutritional Security in Brazil and the Human Right to Adequate Food if the cultivation and the commercialization of genetically modified foods meets Food and Nutritional Security in a developing country.

\section{METHODOLOGY}

In order to achieve the analysis proposed for this study, a bibliographical review was carried out, through a collection research and databases: LILACS (Latin American and Caribbean Literature in Health Sciences), PubMed, Medline, Brazilian legislation and publications from FIOCRUZ (Fundação Oswaldo 
Cruz), CTNBio (Comissão Técnica Nacional de Biossegurança), ANVISA (Agência Nacional de Vigilância Sanitária), Ministries of Brazil (Ministério da Saúde, Ministério do Desenvolvimento Agrário and Ministério do Meio Ambiente) assim como órgãos internacionais, as well as international organizations such as WHO (World Health Organization), FAO (Food and Agriculture Organization), CDC (Center for Diseases Control), Center for Food Safety, Amigos de la tierra internacional, ENSSER (European Network of Scientists for Social and Environmental Responsibility), Commission and EFSA (European Food Safety Authority) of EU Food Policy, and Coalition for a GMFree India with data related to the topic addressed in the present research. We worked with theses and articles that were available in their integral form, submitted and accepted for publication, giving preference to the most recent, but being careful to consult and use the primary sources. The descriptors were: genetically modified organisms (GMOs); transgenic; transgenesis; Genetically Modified Food; Food and Nutritional Security; Human Right to Adequate Food; sustainable production; sustainable agriculture; sustainability; allergenicity; allergies; nutritional composition, nutritional labeling; regulation; compositional analysis, safety assessment, biosafety, human rights; consumer law; toxicity.

According to the bibliographic review of this study based on the Brazilian Food and Nutritional Security Policies, the present research sought to answer the following questions contemplated in Feeding and Nutritional dimensions ${ }^{[30]}$ :

Feeding dimension: It was investigated if genetically modified organisms contain stable, equitable and sustainable food supply to meet population demand.

Nutritional dimension: It was investigated if transgenic foods available for human consumption gather the conditions to promote the health of individuals as well as for their family and community and if these foods ensure adequate biological use.

\section{RESULTS AND DISCUSSION}

\section{First question: feeding dimension}

The safety in the production of transgenics is a topic that has generated much controversy, since with the potential benefits, there are known risks and other risks still unknown. In this case potential losses that may occur with the use of genetically modified organisms when compared to those resulting from technologies commonly used in agriculture are considered risks ${ }^{[32,33]}$. The major problem in risk analysis is to make it impossible to predict the effects in its totality ${ }^{[34]}$. Most of the uncertainties are due to the fact that studies involving transgenesis compare this technology with conventional plantations, rather than with agroecological-based management that is more environmentally friendly ${ }^{[10]}$. Safety is evaluated through four stages: Characterization of the culture of the country, characterization of the process of genetic modification, transferred genes and organism of origin of the recombinant DNA[34].

On the one hand, in certain situations such as places which frequent droughts or inappropriate soil for agriculture, transgenic foods develop better. In addition, they have a longer shelf life and because they are more resistant against insects, weeds and other pests they do not need chemicals[35].

On the other hand, to confer protection against insects, foods can be modified with different $\mathrm{Bt}$ proteins (Bacillus thuringiensis). It turns out that an effect that can come from the planting of transgenics with insecticidal properties of massive form is the development of resistant insects, with the consequent loss of effectiveness of the desired insecticidal characteristics. It is possible to avoid or minimize this damage, but this process requires the hiring of trained professionals, which is expensive. These professionals plan actions that prevent or delay insect resistance and these plans are complex because they can not be generalized, since the characteristics of each site of planting and the biology of the various pests, is different ${ }^{[36]}$.

A deleterious effect on the environment may come from the fact that transgenic crops expressing transgene insecticides for pest control reach non-target organisms that are beneficial to the environment because they are predators and pest parasites, causing another problem for farmers, who will need to use herbicides with more active ingredients ${ }^{[3]}$.

Other negative impacts arising from the use of the main herbicides associated with the cultivation of genetically modified organisms are described. Research 
on glyphosate, previously considered safe and glufosinate ammonium, both associated with certain transgenic varieties, suggests that these products may be deleterious to human health $[38,39,40,41]$. In addition, there is the association of genetically modified plants with herbicides formulated with 2,4-dichlorophenoxyacetic $(2,4 \mathrm{D})$, authorized in Canada, the United States and Brazil, added to glyphosate and glufosinate ammonium, whose effectiveness in controlling weeds had been reduced due to the resistance of the plants ${ }^{[0]}$. Studies relate 2,4D herbicide exposure, to cases of tumors such as soft tissue sarcoma, Hodgkin's disease and nonHodgkin's lymphoma in humans ${ }^{[42]}$ and other deleterious effects ${ }^{[43]}$.

In spite of that, the Brazilian National Technical Commission on Biosafety (CTNBio) does not take into account the potential toxic effects on crops and food products with these products ${ }^{[10]}$.

It is important to emphasize, that transgenesis may still pose as a threat to the biodiversity, which is an indispensable element for environmental sustainability. On the one hand, technology allows increasing the production and the variety of foods. On de other hand, it can cause loss or alteration of the genetic patrimony of plants and seeds and can lead to dramatic increase of use of pesticides [33,4]].

Damage to the environment can be caused even by the uncontrolled transmission of transgenics. An illustrative example is red rice, which invades commercial rice crops, making it the recipient and transmitter of genetically modified rice ${ }^{[45]}$.

The cultivation of transgenic crops may ultimately result in the dominance of producers and dependence of developing countries in relation to industrialized countries. According to experts, this would occur due to the probability of food production being controlled by these countries in the future ${ }^{[35]}$. Likewise, with the high concentration and market power of transgenic seeds, smaller producers tend to be more and more dependent on the companies that control practically the entire market, thus compromising the income of a segment of the population ${ }^{[46]}$ and, consequently, access to food.

In this sense, policies, such as access to agricultural credit for small landowners, to improve agricultural productivity, with better infrastructure in basic sanitation and protection of the environment, could increase income and, consequently, access to food, without compromising health ${ }^{[30]}$.

\section{Second question: nutritional dimension:}

One of the benefits of transgenic foods relates to the improvement in nutritional quality of foods ${ }^{[47,34]}$.

In this regard, however, there are also positive and negative arguments.

Proponents of technology claim that an increase in nutritional potential, such as by increasing the concentration of vitamins and amino acids in food, could solve the problem of malnutrition and nutritional deficiencies in the world, especially in underdeveloped

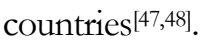

However, the risk to be taken with the consumption of these foods, by the possibility of unintended effects, does not correspond to their probable benefits ${ }^{[48]}$ and that nutritional safety cannot be guaranteed ${ }^{[49]}$.

The scientific knowledge base on the subject is still insufficient ${ }^{[50]}$ and the uncertainties involved are strengthened both by the lack of results in humans and by the inadequate interpretation of several experiments conducted with animals that bring inconsistent methodologies and results ${ }^{[1]}$.

However, regarding to food safety, other points should be highlighted. Among them, the issue of access - since nutritional deficiencies are not related only to food production, but also to several other factors. Therefore, it is not enough to produce foods with higher nutritional quality, if the population does not have access to them ${ }^{[30}$. Even if these foods are nutritionally superior, the development of policies and strategies aimed at increasing people's income, becomes critical in this case ${ }^{[48]}$.

Another aspect concerning the effect of transgenesis on the human organism concerns allergenicity.

Some points about the allergenicity of transgenics should be considered: The first point concerns the possibility that a known allergen can be 
transferred to a non-allergenic target culture with the creation of a new allergen. The other point is about the technological evidence used to produce genetically modified food, which in itself already poses a "threat" to the creation of allergenic food ${ }^{[35]}$ once a protein that is already known as allergenic is used for transgenesis, it is very likely that this protein will remain with the allergenic properties ${ }^{[52]}$. It's important to consider that the main allergenic foods are of a protein nature[53].

On the other hand, there are also advocates of the matter, who claim that since the ability to cause allergies is related to food proteins, this can occur with both: conventional and transgenic foods. In any case, there is no way to assess the allergenic potential for humans, based solely on the composition of the food ${ }^{[54]}$.

In this way, the Codex Alimentarius Commission (2003) ${ }^{[5]}$ proposes the consideration of some factors to approve transgenic foods: the gene source, if there is similarity of the amino acid sequence of the evaluated protein related to known allergens, protein stability to pepsin digestion when subjected to an "in vitro" test and, if necessary, clinical or serological tests in humans (in this case, the reactivity of the new protein with IgE immunoglobulin is investigated) when exposed to this protein source which is being analyzed. Said amino acid sequence comparison may be carried out at the beginning of the production process of the cultivation of a transgenic food and, if it is found that there is a presumption of allergenic potential, there may be a need to use one or more other procedures referred to, according to what's proposed by the Codex Alimentarius Commission (2003), to confirm whether there is this potential allergen or even to suspend the use of the desired protein in the transgenic. Ultimately, whenever a transgenic protein binds to $\mathrm{IgE}$ antibodies from allergic individuals, it will not be released commercially.

In relation to the amino acid sequence, there are criteria that define analogy, but even the absence of analogy between proteins is not a guarantee of absence of allergenicity[53].

As an example of the research that precedes the availability of a transgenic food, the allergy demonstrated by genetically modified soybeans can be cited due to the allergenic potential of the Brazilian nut and not of soybeans before transgenesis. Clinical trials were carried out that detected a positive reaction between human $\operatorname{IgE}$ and protein from this modified soybean, in addition to other physic-chemical and biochemical results ${ }^{[5]}$ which made the product commercialization unfeasible ${ }^{[48]}$.

Another study worth mentioning is the one conducted by the Center for Disease Control in which an investigation was carried out to verify if genetically modified maize, approved for animal feed and containing Bacillus thuringiensis - $B t$, but not released to humans because of the presence of the protein Insecticide, Cry9C, potentially allergenic to humans, has contaminated human food. One group of individuals with allergic reactions was submitted to the study with two other groups, and in the end, despite the hypothesis pointing to allergenicity, it was not possible to demonstrate that Cry9C protein was actually responsible for adverse health reactions. In this study, therefore, no allergenicity of the insecticidal protein was demonstrated. However, animal food contaminated human food, what was unexpected ${ }^{[5]}$.

In general, therefore, it is noted that if all precautions are taken, there will be no risk of allergies in non-allergic individuals previously, but once transgenesis mixes genes from different organisms, the subject that deserves further evaluation becomes the information to the customer on the food ingested.

The labeling of transgenic products has been a subject of much discussion for a number of years, mainly due to two issues: the first concerns the interests of the food industry, which claims that labeling is expensive and the second concerns the consumer right to information, which allows the decision-making power on foods consumed and whose innocuity are still discussed $[58,59,60]$.

Another equally relevant issue is the importance of an adequate bio-vigilance, which is possible with labeling, which allows us to trace the origin of a food, when facing the occurance of possible problems $[59,60]$.

In Brazil, the Consumer Protection Code, Law no 8.078 of 1990 , establishes the basic right of the consumer to have access to "...adequate and clear information about the different products and services, with the correct specification of quantity, characteristics, composition, quality and price, as well as 
the risks they present'[61]. In this way, the Consumer Defense Code brings the market's obligations towards the consumer, giving them information with transparency[2].

Consumer rights must be understood in its scope, it not only concerns about the consumption relations, but also relates to crimes against the popular economy, the free distribution of products necessary for the people and the legislation on the intervention of the economic domain ${ }^{[62]}$.

Regarding the regulation of the labeling of transgenics, there are Law 11.105/2005 which reaffirms the obligation to label products for human or animal consumption containing or produced from transgenic organisms or derived products; Normative resolution $7 / 2009$ which provides for the obligation of information when there is release of food containing genetically modified microorganisms and animals with allergenic effect[63]; Decree no 4.680/2003 which regulates the right to information ${ }^{[6]}$; and Administrative Rule no 2.658/2003 which establishes a symbol ("T") surrounded by a triangle with a yellow background) and the words "may contain transgenic product" or "may contain ingredient produced from transgenic product", in case of products of vegetable originin ${ }^{[65]}$.

Despite the legal basis, the labeling of these foods is rarely fulfilled in Brazil[66]. In relation to the producer, for example, it is not only the question of the cost that justifies the noncompliance of the law, but the exposure of a negative image, that can generate a contrary publicity ${ }^{[67]}$. This aspect of the image seems to be very relevant for the producers, given that, currently, public opinion plays a strong role in the organization of the world food market, being able to put a great pressure on large supermarket chains ${ }^{58]}$.

The segment of consumer rights is the least informed about biotechnology. The defenders and antagonists of transgenesis have different understanding and disseminate information according to their knowledge[62].

It is therefore necessary that the scientific community and society have a clear and conscious communication and that there are more researches to identify the impacts of transgenics on human health and the environment, which should be disseminated to the whole society. In addition, it is necessary transparency in the processes of releasing genetically modified products by competent organizations ${ }^{[62]}$.

In the light of the foregoing, although studies point out that consumers are favorable mandatory labeling of transgenic products ${ }^{[68]}$, education is necessary in this regard, empowering the consumer about their choices ${ }^{[67]}$.

Finally, the importance of Food and Nutritional Education as contributing to the achievement of Food and Nutritional Security is emphasized, since in exercising their right to citizenship, the individual and the community to which they belong can evaluate the reality, propose and demand solutions, with the necessary transformations, promoting the autonomy for more sustainable choices and food practices ${ }^{[30]}$.

\section{CONCLUSION}

Based on the concepts of Food and Nutritional Security in Brazil and the Human Right to Adequate Food it was concluded that:

Transgenesis appear to increase food supply, and may eventually meet the sufficiency requirement, but studies suggest that this technology may not always be stable, and may also favor large ones, to the detriment of small producers and, equally worryingly, threaten environmental sustainability, as it can increase toxicity and endanger the planet's biodiversity. In addition, the food supply to be equitable, must take into account the issue of access to food of all segments of the population, including the income generation for the smaller producers, which does not occur with the transgenic food technology.

In regard to the nutritional question, the scientific knowledge base is still incipient, especially when taking into account the insufficiency of epidemiological studies. As for allergenicity, there are no evidences that transgenic foods are more allergenic than conventional foods, especially since there is a very cautious protocol for the release of transgenic seeds, but there is also a concern about the lack of control for the release of potentially allergenic foods and the lack of clear information to the consumer, a situation that affects not only the individual, but also a large part of the population, which, even without knowing the 
Food security and nutritional and transgenic food. Fiore $e t a l$.

technology of transgenesis, is subject to the consumption of genetically modified foods. In this context, the nutritional education could contribute to the achievement of the Food and Nutritional Security.

Finally, we refer to the concept of Food and Nutritional Security, which is indivisible and refers again to the Brazilian Policies on Food and Nutritional Security discussed in this article, and its interface with the Human Right to Adequate Food, as well as the commitment of Brazil to respect, protect and fulfill the economic, social and cultural rights of citizens. The inconsistency of the epidemiological studies and the various aspects that seem to threaten the sustainability and the supply of adequate and healthy food with the transgenesis, and the release of these foods, in spite of that, show that the commitment of the Food and Nutritional Security guarantee has not been fulfilled in a developing country.

\section{Notes}

All authors have made a significant contribution to the findings and methods in the paper and have read and approved the final draft.

All authors declare no conflicts of interest in relation to this manuscript and have no funding to declare.

\section{REFERENCES}

[1] Custódio MB, Furquim NR, Santos GM, Cyrillo DC. Segurança Alimentar e Nutricional e a construção de sua política: uma visão histórica. Segur. Aliment. Nutr. 2011;18(1):1-10.

[2] Brasil. Lei no 11.346, de 15 de setembro de 2006. Cria o Sistema Nacional de Segurança Alimentar e Nutricional - SISAN com vistas em assegurar o direito humano à alimentação adequada e dá outras providências. Diário Oficial da União. 16 set 2006.

[3] Brasil. Decreto no 592, de 06 de julho de 1992. Dispõe sobre o Pacto Internacional sobre Direitos Civis e Políticos, o Brasil se comprometeu em assumir suas obrigações sobre direitos humanos e dá outras providências. Diário Oficial da União. 07 jul 1992.

[4] Albuquerque MFM. A segurança alimentar e nutricional e o uso da abordagem de direitos humanos no desenho das políticas públicas para combater a fome e a pobreza. Rev. Nutr. 2009;22(6):895-903.

[5] Brasil. Decreto o 7272, de 25 de agosto de 2010. Regulamenta a Lei no 11.346, de 15 de setembro de 2006, que cria o Sistema Nacional de Segurança Alimentar e Nutricional - SISAN, e institui a
Política Nacional de Segurança Alimentar e Nutricional - PNSAN, e dá outras providências. Diário Oficial da União. 26 ago 2010.

[6] Brasil. Câmara Interministerial de Segurança Alimentar e Nutricional (CAISAN), aprova o Plano Nacional de Segurança Alimentar e Nutricional 2016 - 2019 (PLANSAN) [Internet]. Brasilia (DF); 2016 [acesso em 09 dez 2016]. Disponível em: http:/ /www.cfn.org.br

[7] Brasil. Ministério da Saúde, Secretaria de Atenção à Saúde. Departamento de Atenção Básica. Política Nacional de Alimentação e Nutrição - PNAN. Brasília (DF): Ministério da Saúde; 2012. (Série B - Textos Básicos de Saúde).

[8] Brasil. Constituição (1988). Constituição da República Federativa do Brasil. Brasília (DF): Senado; 1988.

[9] Faleiro FG, Andrade SRM. Biotecnologia, transgênicos e biossegurança. Planaltina (DF): Embrapa Cerrados; 2009.

[10] Ferment G, Melgarejo L, Fernandes GB, Ferras JM. Lavouras Transgênicas - riscos e incertezas: mais de 750 estudos desprezados pelos órgãos reguladores de OGMs. Brasilia: Ministério do Desenvolvimento Agrário; 2015.

[11] Brasil. Lei no 8.974, de 05 de janeiro de 1995. Estabelece normas para o uso das técnicas de engenharia genética e liberação no meio ambiente de organismos geneticamente modificados, autoriza criação da Comissão Técnica Nacional de Biossegurança (CTNBio), e dá outras providências. Diário Oficial da União. 05 jan 1995.

[12] Brasil. Lei no 11.105, de 24 de março de 2005. Regulamenta os incisos II, IV e V do $\int 10$ do art. 225 da Constituição Federal, estabelece normas de segurança e mecanismos de fiscalização de atividades que envolvam organismos geneticamente modificados OGM e seus derivados, cria o Conselho Nacional de Biossegurança - CNBS, reestrutura a Comissão Técnica Nacional de Biossegurança - CTNBio, dispõe sobre a Política Nacional de Biossegurança PNB, revoga a Lei no 8.974, de 5 de janeiro de 1995, e a Medida Provisória no 2.191-9, de 23 de agosto de 2001, e os arts. 5o, 6o , 7o, 8o, 9o, 10 e 16 da Lei no 10.814, de 15 de dezembro de 2003, e dá outras providências. Diário Oficial da União. 28 mar 2005.

[13] Smith JM. Roleta genética: riscos documentados dos alimentos transgênicos sobre a saúde. São Paulo: Editora João de Barro; 2009.

[14] FAO/WHO - Food and Agriculture Organization of the United Nations/World Health Organization. Evaluation of allergenicity modified foods: Report of a Joint FAO/WHO Expert Consultation on Allergenecity of Foods Derived from biotechnology. Rome: FAO; 2001.

[15] Conferência das Nações Unidas sobre o Meio Ambiente e Desenvolvimento (1992: Rio de Janeiro), Conferência das Nações Unidas sobre o Meio Ambiente e Desenvolvimento, Agenda 21. Brasilia (DF): Biblioteca Digital da Câmara dos Deputados; 1995.

[16] Moriconi PR, Tonietti PO, Moreno LZ, Matté GR. Regulação de Organismos Geneticamente Modificados de uso agrícola no 
Brasil e sua relação com os modelos normativos europeu e estadunidense. R. Dir. Sanit. 2013/2014;14(3):112-31.

[17] Brasil. Ministério do Meio Ambiente [internet]. Brasília: Organismos Geneticamente Modificados; 2016 [atualizado em 23 nov 2016; acesso em 10 ago 2016]. Disponível em: http://www.mma.gov.br/biodiversidade/biosseguranca/organism os-geneticamente-modificados

[18] World Health Organization - WHO. Food Standard Programme, Codex Alimentarius Commission, Twenty-Fifth Session. Report. Appendix III, Guideline for the conduct of food safety assessment of foods derived from recombinant - DNA plants and Appendix IV, Annex on the assessment of possible allergenicity, p. 47-60. Rome: WHO; 2003.

[19] Amigos de la tierra internacional. ¿Quién se beneficia con los cultivos transgénicos? Una industria fundada en mitos [Internet]. Amsterdam: Amigos de La Tierra; 2014 [acesso em 09 dez 2016]. Disponível em: http://www.foeeurope.org

[20] Just Label It! Senate defeats DARK Act in major win for consumers [Internet]. Washington (DC); 2016 [acesso em $11 \mathrm{dez}$ 2016]. Disponível em: http://www.justlabelit.org/pressroom/senate-defeats-dark-act-in-major-win-for-consumers

[21] Just Label It! Food Companies Should Keep Clear, On-Pack GMO Labels [Internet]. Washington (DC); 2016 [acesso em $11 \mathrm{dez}$ 2016]. Disponível em: http://www.justlabelit.org/pressroom/food-companies-should-keep-clear-on-pack-gmo-labels

[22] Viana FB. Transgênicos: alguns aspectos. R D Priv. 2009;38:142.

[23] European Network of Scientists for Social and Environmental Responsibility - ENSSER. Statement: no scientific consensus on GMO safety [Internet]. Berlin; 2013 [acesso em 11 dez 2016]. Disponível em: http://www.ensser.org/increasing-publicinformation/no-scientific-consensus-on-gmo-safety

[24] Shao Q, Chin K-V. Survey of American food trends and the growing obesity epidemic. Nutrition Research and Practice. 2011;5(3):253-259.

[25] Swanson LS, Leu A, Abrahamson J, Wallet B. Genetically engineered crops, glyphosate and the deterioration of health in the United States of America. Journal of Organic Systems: 2014;9(2):637.

[26] Center for Food Safety. About genetically engineered fish [Internet]. Washington (DC); 2016 [acesso em 15 dez 2016]. Disponível em: http://www.centerforfoodsafety.org

[27] Coalition for a GM - Free India (2012) - 10 Years of Bt Cotton: False Hype and Failed Promises, Cotton farmers' crisis continues with crop failure and suicides [Internet]. Malaysia; 2012 [acesso em 15 dez 2016]. Disponível em: https://www.biosafetyinfo.net/file_dir/551137394f82a8adac3ad.pdf
[28] Yunzhang J. Item 1 - Commercialization of genetically modified staple food: not to proceed for 5 years except for corn [Internet]. Penang: Biosafety Information Center; 2011 [acesso em 15 dez 2016]. Disponível em: https://www.biosafety-info.net

[29] EU Food Policy. Commission and EFSA agree need for twoyear GMO feeding studies [Internet]. Norwich: GM Watch; 2013 [acesso em 20 dez 2016]. Disponível em: http://www.gmwatch.org/news/archive/2012/14524-

commission-and-efsa-agree-need-for-two-year-gmo-feeding-studies

[30] Cervato AMC, Fiore EG, Redolfi SCS. Guia de Segurança Alimentar e Nutricional. São Paulo: Manole; 2015.

[31] Câmara MCC. Regulamentação e atuação do Governo e do Congresso Nacional sobre os alimentos transgênicos no Brasil: uma questão de (in)segurança alimentar [tese]. Rio de Janeiro: Escola Nacional de Saúde Pública Sérgio Arouca; 2012.

[32] Fukuma P. Regulamentação da Biotecnologia no Brasil. São Paulo: Conselho de Informações sobre Biotecnologia (CIB); 2003.

[33] Singh OV, Ghai S, Paul D. Genetically modified crops: success, safety assessment, and public concern. Appl Microbiol Biotechnol. 2006;71(5):598-607.

[34] Costa TEMM, Dias APM, Scheidegger EMD, Marin VA. Avaliação de risco dos organismos geneticamente modificados. Ciênc. Saúde Coletiva. 2011;16(1):327-336.

[35] Anilakumar KR, Bawa AS. Genetically modified foods: safety, risks and public concerns - a review. J Food Sci Technol. 2013;50(6):1035-1046.

[36] MacIntosh SC. Managing the risk of insect resistance to transgenic insect control traits: practical approaches in local environments. Pest Manag Sci. 2009;65:100-106.

[37] Hilbeck A, Baumgartner M, Fried PM, Bigler F. Effects of transgenic Bacillus thuringiensis corn-fed prey on mortality and development time of immature Chrysoperla carnea (Neuroptera: Chrysopidae). Environ Entomol. 1998;27:480-487.

[38] Mino CP, Sánchez ME, Arévalo M, Munõz MJ, Witte T. Evaluation of DNA damage in a Ecuadorian population exposed to glyphosate. Genetics and Molecular Byology. 2007;30(2):456-460.

[39] Roos AJ, Blair A, Rusiecki JA, Hoppin JA, Svec M, et al. Cancer Incidence among Glyphosate-Exposed Pesticide Applicators in the Agricultural Health Study. Environmental Health Perspectives. 2005;113(1):49-54.

[40] Marc J, Lorillon OM, Bellé R. Glyphosate-based pesticides affect cell cycle regulation. Biology of the Cell. 2003;96:245-249.

[41] Matsumura M, Takeuchi C, Hishikawa K, Fujii T, Nakaki T. Glufosinate ammonium induces convulsion through N-methil-D- 
Food security and nutritional and transgenic food. Fiore et al.

aspartate receptors in mice. Neuroscience Letters. 2001;304(12):123-125.

[42] Hoar SK, Blair A, Holmes FF, Boysen CD, Robel RJ, et al. Agricultural Herbicide Used and Risk of Lymphoma and Soft-Tissue Sarcoma. JAMA. 1986;256(9):3351.

[43] Bharadwaj L, Dhami K, Schneberge D, Stevens M, Renaud C, Ali A. Altered gene expression in human hepatoma HepG2 exposed to low-level 2,4-dichlorophenoxyacetic acid and potassium nitrate. Toxicology in Vitro. 2005;19(5):603-619.

[44] Rojas IRG, Alonso JCG, Trujillo T. Los alimentos transgênicos y La salud humana. Rev. Mediciego. 2012;18:1-10.

[45] Giraldo AC. Cultivos Trangénicos: entre los riesgos biológicos y los benefícios ambientales y econômicos. Acta Biol. 2011;16(3):1-17.

[46] Costa NL, Santana AC. Poder de mercado e desenvolvimento de novas cultivares de soja transgênicas e convencionais: análise da experiência brasileira. Rev. Ciênc. Agrar. 2013;56(1):61-68.

[47] Alves GS. A Biotecnologia dos Transgênicos: Precaução é a palavra de ordem. Holos. 2004;20:1-10.

[48] Acosta O, Chaparro A. Genetically modified food crops and public health. Acta Biol. Colomb. 2008;13(3):3-26.

[49] Konig A, Cockburn A, Crevel RWR, Debruyne E, et al. Assessment of the safety of foods derived from genetically modified (GM) crops. Food and Chemical Toxicology. 2004;42(7):1047-1088.

[50] Nodari RO, Guerra MP. Plantas transgênicas e seus produtos: impactos, riscos e segurança alimentar (Biossegurança de plantas transgênicas). Rev. Nutr. 2003;16(1):105-116.

[51] Reyes MS, Rozowski JN. Alimentos Transgénicos. Rev. Chil. Nutr. 2003;30(1): 21-26.

[52] Losada AO, Fonseca CAG. Alimentos Transgénicos y Alergenicidad: transgenic foods and allergenicity. Rev. Fac. Med. 2007;55:251-269.

[53] Pereira ACS, Moura SM, Constant PBL. Alergia alimentar: sistema imunológico e principais alimentos envolvidos. Semina: Ciências Biológicas e da Saúde. 2008;29(2):189-200.

[54] Delaney B, Astwood JD, Cunny H, Conn RE, Guicheney CH, Macintosh S, et al. Evaluation of protein safety in the context of agricultural biotechnology. Food Chem Toxicol. 2008;46:71-97.

[55] Codex Alimentarius Comission. Twenty fifth session Report of the third session of the Codex Ad Hoc Intergovernmental task force on foods derived from biotechnology, Yokohama, Japan 4-8 march 2002. Rome; 30 june - 5 july 2003 (Note: This document incorporates Codex Circular Letter CL 2002/9-FBT).
[56] Nordlee JA, Taylor SL, Townsend JA, Thomas LA, Bush RK. Identification of a Brazil-nut allergen in transgenic soybeans. N Engl J Med. 1996;334:688-692.

[57] CDC - Centers for Diasease Control and Prevention. Investigation of Human Health Effects Associated with Potential Exposure to Genetically Modified Corn; A Report to the U. S. Food Drug Administration from de Centers for Disease Control and Prevention. Atlanta: CDC; 2001.

[58] Pessanha LDR, Wilkinson J. Transgênicos provocam novo quadro regulatório e novas formas de coordenação do sistema agroalimentar. Caderno de Ciências e Tecnologia. 2003;20(2):263303.

[59] Câmara MCC, Marinho CLC, Guilam MCR, Nodari RO. Transgênicos: avaliação da possível (in)segurança alimentar através da produção científica. História, Ciências, Saúde. 2009;16(3):669-681.

[60] Câmara MCC, Nodari RO, Guilan MCR. Regulamentação sobre (in)segurança no Brasil: a questão dos alimentos transgênicos. Interthesis. 2013;10:261-286.

[61] Brasil. Lei no 8.078, de 11 de setembro de 1990. Estabelece normas de proteção e defesa do consumidor e dá outras providências. Diário Oficial da União. 11 set 1990.

[62] Vieira ACP, Buainain AM, Lima F, Vieira PA, Capacle VH. Debates atuais sobre a segurança dos alimentos transgênicos e os direitos dos consumidores. In: Anais do XLIV Congresso da Sociedade Brasileira de Economia e Sociologia Rural - questões agrárias, educação no campo e desenvolvimento, 2006; Fortaleza. Brasilia: Sociedade Brasileira de Economia e Sociologia Rural; 2006. p. 198.

[63] Brasil. Resolução Normativa no 07, de 07 de abril de 2009. Dispõe sobre as normas para liberação planejada no meio ambiente de microorganismos e animais geneticamente modificados (MGM e AnGM) de Classe de Risco I e seus derivados. Comissão técnica Nacional de Biossegurança. Diário Oficial da União. 07 abr 2009.

[64] Brasil. Decreto no 4680/2003. Regulamenta o direito à informação, assegurado pela Lei no 8.078 , de 11 de setembro de 1990, quanto aos alimentos e ingredientes alimentares destinados ao consumo humano ou animal que contenham ou sejam produzidos a partir de organismos geneticamente modificados, sem prejuízo do cumprimento das demais normas aplicáveis. Diário Oficial da União. 24 abr 2003.

[65] Brasil. Lei Administrativa 2658/2003. Define o símbolo de que trata o art. $2^{\circ}, \$ 1^{\circ}$, do Decreto 4.680 , de 24 de abril de 2003 , na forma do anexo à presente portaria. Diário Oficial da União. 26 dez. 2003.

[66] Salazar AL. A informação sobre transgênicos no Brasil. In: Zanoni M, Ferment G. Transgênicos para quem? Agricultura Ciência e Sociedade. Brasília: MDA; 2011. p. 294-308. 
[67] Carter CA, Gruère GP, Mandatory Labeling of Genetically Modified Foods Does it Really Provide Consumer Choice? AgBioForum. 2003;6(1, 2):68-70.

[68] Ponce MIS, Valero JS, Berghe CW, Los usuários ante los alimentos genéticamente modificados y su información em el etiquetado; Os usuários frente aos alimentos geneticamente modificados e a informação na etiqueta. Rev. Saúde Pública. 2014;48(1):154-169. 